\title{
The imperatives of financial policy in the sphere of the digital economy: impacts on increasing investment activity and tax potential of Russian regions
}

\author{
Agnessa Inshakova \\ Volgograd State University, \\ Institute of Law, \\ Professor \\ Head of the department of civil and international \\ particular law \\ Volgograd, Russia \\ gimchp@volsu.ru, ainshakova@ list.ru
}

\author{
Alexander Goncharov \\ Volgograd State University, \\ Institute of Law, \\ Professor, \\ Department of civil and international particular law \\ Volgograd, Russia \\ gimchp@volsu.ru, goncharova.sofia@gmail.com
}

\author{
Olesya Kazachenok \\ Volgograd State University, \\ Institute of Law, \\ Associate Professor, \\ Department of civil and international particular law \\ Volgograd, Russia \\ gimchp@volsu.ru, kazachenok@mail.ru
}

\begin{abstract}
The article studies the influence of certain imperative decisions of the Russian financial authorities on the increase of investment activity and tax potential of Russian regions. In particular, the law published in early 2018 by the Ministry of Finance of the Russian Federation is being considered. This document is being created for the legal regulation of new virtual digital objects, transactions with which in different countries around the world are anonymously conducted over the past 8 years by any persons in the information and communication network "Internet" using special computer programs. The authors reveal the essence and types of digital objects, and critically evaluate the low level of legislative technology presented by the bill. The authors substantiates the proposals on the need to change the name of the created Federal law, to clarify and revise its conceptual apparatus. The draft law is analyzed by the authors in terms of the possibility of its application to increase the tax potential and investment activity at the level of Russian regions. The authors concluded that the presented model of state regulation will not have a positive impact on the development of the investment sphere is substantiated.
\end{abstract}

Keywords - financial policy, digital objects, ciphers, Internet, anonymity, game, protection of rights, tax base, investment activity, regional economy, regions of Russia

\section{INTRODUCTION}

The institutional financial policy, being an imperativelyimperious form of state regulation of social relations, is based on scientifically-grounded concept of economic growth of the country. It establishes the basis for the development of private-economic Finance, the strategy for the formation and use of cash funds, the implementation of tactical decisions on the mobilization of tax and non-tax revenues, their distribution, expenditure and control in the performance of the state's tasks and functions, belongs to the Federal center. All decisions in the field of financial policy are implemented in real practice through strict compliance with the regulations of financial institutions, both at the regional and at the municipal levels, as a rule, such decisions relate to the activities of every single organization, every single person[1].

The issues of stimulating the activities of business entities and in conjunction with them - the development of the tax base and investment activity at the sub-Federal level have always been and continues to be a part of the country's financial policy measures. According to the results of the 2017 in the Volgograd region the growth of tax revenues has 
ensured: organizations profit tax - 20,1 bill. rub - an increase of $3.5 \%$, the physical persons incomes tax- 17.6 bill. rub. - an increase of $2.2 \%$, organizations property tax -9 bill. - an increase of $5.1 \%$, the tax levied in connection with application of simplified system -3.9 bill. rub. - an increase of $13.3 \%$. In 2017, revenues from corporate income tax exceeded the forecast by $1.1 \%$. According to the transport tax, which is traditionally considered to be one of the problematic, revenues amounted to 1.8 billion rubles, which is $9.4 \%$ higher than the same period of 2016 and $13.9 \%$ higher than in 2017 [2].

However, the dynamics of tax revenue growth is not accompanied by an increase in investment activity in our region. Thus, in the "Comments on the state and business" prepared by experts of the NRU «Higher school of economics», in July 2017, the Volgograd region is recognized as one of the two most problematic regions of Russia, where 5 simultaneously decreased sectors of the economy: industry, construction, retail and wholesale trade, paid services [3]. Sectoral imbalances in the economy of our region have long been a well-known problem that, unfortunately, is being resolved very slowly [4].

At the same time, in June 2017 at the St. Petersburg economic forum, the President of the Russian Federation Vladimir Putin said that "The Digital economy is not a separate industry, in fact, it is the basis that allows you to create qualitatively new models of business, trade, logistics, production, changes the format of education, health care, public administration, communications between people, and, therefore, sets a new paradigm for the development of the state, the economy and society as a whole. But, all decisions should be made taking into account information security of the state, business and citizens" [5].

One of the notable imperatives in this regard is the attempt of the Ministry of Finance of the Russian Federation to submit to the public the first Federal law for the legal support of the digital economy. Let us consider further what impact the draft law will (will not) be able to have on the development of tax potential and investments at the sub-federal level of Russia.

\section{MATERIALS AND Methods (Model)}

This article uses Federal laws and regulations of the Ministry of Finance of the Russian Federation. The provision on accounting "Intangible assets control" (PBU 14/2007) (approved by order of the Ministry of Finance of Russia from 27.12.2007 № 153n, with changes from 25.10.2010 No. 132n, from 24.12.2010 No. 186n, from 16.05.2016 No. 64n), the Provision on accounting "Accounting for Financial Investments" PBU 19/02 (approved by order of the Ministry of Finance of Russia from 10.12.2002 No. 126n, as amended by orders of the Ministry of Finance from 18.09.2006 № 116n, from 27.11.2006 № 156n, from 25.10.2010 No. 132n, from 08.11.2010 № 144n, from 27.04.2012 No. 55n, from 06.04.2015 No. 57n) were analyzed in the perspective of finding the essence of digital objects. Also in the relationship with them was investigated: the Federal law of 10.12.2003 № 173-FL (ed. from 29.12.2017) "On Currency Regulation and Currency Control"; Federal law of 21 November 2011 No.
325-FL (ed. from 18.07.2017) "On organized Governmental Auction". A critical assessment was made with regard to the Federal law of the Ministry of Finance of Russia "On Digital Financial Assets".

The study is supported by the current statistical base and analytical periodicals of the NRU "Higher school of Economics" ("Comments on the state and business"). In order to identify the possible practical benefits of the draft law of the Ministry of Finance of Russia for the development of the real sector on the regional level, in particular - the nanoindustry, the authors relied on the O. V. Inshakov school research.

The General method of research - dialectical materialism is the basis of the methodological model of the study. As a part of General scientific methods are applied: logical, analysis and synthesis, ascent from abstract to concrete, systematic, methods of analogy and generalization, the method of hypothesis; particular scientific methods are presented, including: statistical, mathematical, philological interpretation, comparative legal, formal-legal, functional.

\section{RESULTS AND DISCUSSION}

\section{A. The financial-digital miracle-assets}

Deeply developed, scientifically grounded imperative decisions of the financial authorities have a very noticeable impact on the increase in investment activity and tax potential of the Russian regions. Among such imperatives, of course, are the bills which are introduced the domestic legislator of the Ministry of Finance of Russia. In January 2018 the draft Federal Law "On Digital Financial Assets" was published by the Ministry of Finance of the Russian Federation [6]. Thus, in 2017, the position of the Federal Executive body in the financial sphere announced as a tough conservative regarding the "digital financial assets" was finally publicly presented.

On the basis of name of the proposed regulatory act, it can be seen that, according to the lawyers who developed the text of the draft law, there are stable public relations in the Russian Federation about certain assets that need to be regulated. As we have further found out, it is necessary, first of all, in the fiscal interests of the state itself, declaratively also in order to protect the rights of the parties of these relations. In the understanding of the Ministry of Finance of Russia, these newly minted asset of the XXI century have 2 special qualities, firstly, it's digital assets, and secondly, both the same assets and financial ones.

Initially, it should be borne in mind that these digital objects (we believe that there is no reason to call them assets) people will never be able to see like material things, a person can see these digital objects only on the screen of the computer monitor in the form of numbers (huge numbers) inside special tables (registers). At first glance, based on the regulations of the Ministry of Finance of Russia, you can try to consider these special objects as intangible assets of a legal entity with a relatively small stretch. In point 3 of Provision of the Ministry of Finance of the Russian Federation [7] we can see 7 signs of recognition of asset as intangible assets of legal entity which considers them on the its balance. In interpretation of Position of the Ministry of Finance of the 
Russian Federation [7] the intangible asset represents an object:

- with prospects of economic benefits;

- beneficial to the legal entity to which it belongs;

- discrete, detachable from other objects;

- will be used by a legal entity more than 1 year;

- not intended to resale for 1 year;

- has a fixed original purchase price;

- it has no material form.

We believe that the depreciation of digital objects is impossible, therefore, in this part, assignment of these digital objects to intangible assets of a legal entity is unacceptable. In addition, we believe that any asset is an asset only if it is a positive public good, designed to meet legitimate and urgent moral and valid human needs in the present moment or at a certain date in the future. Let us clarify here that operations with digital objects are carried out anonymously by ordinary people around the world, using personal computers, and there is no need to conduct these operations under the mask of a legal entity, with its cumbersome legal structure.

Unless for legal entities digital objects can be at least hypothetically compared with the normatively regulated intangible assets, the legal regulation of the relationship of ownership of digital objects to an individual which not an individual entrepreneur, at the beginning of 2018 is not yet fully available.

The first unique asset quality mentioned in the title of the draft Federal law - digital - should be understood quite literally. Such an asset of the XXI century is an entry in numerals of a huge number, for example 35278311734619042357098500868790785326998466574056 40458400791312963934276590887 in a special database. Whereas an asset is ultimately a benefit, some utility, in this part digital object can also bring economic benefit to the entity to which it belongs. The subject transmitting, or rather rewriting, "numbers" belonging to it into the electronic wallet of another entity in exchange it can obtain the material assets, work performance, services delivery, the transfer of property rights, by using the same "numbers" as a means of payment, namely as a money surrogate. It should be noted that already in article 2 of the draft Federal Law "On Digital Financial Assets" it is proposed to consolidate the norm about that "The digital financial assets are not a legal means of payment at the Russian Federation territory."

The second not unique quality of assets mentioned in the title of the draft Federal Law is financial. In our opinion, lawyers of the Ministry of Finance of Russia unreasonably included this qualitative characteristic in the name of the created Federal law. Financial assets or financial investments of a legal entity are regulated, for example, by the Regulations of the Ministry of Finance of the Russian Federation [8]. In point 2 of Provision of the Ministry of Finance of the Russian Federation [8] disclosed 3 signs of recognition of asset by financial investment for legal entity which considers them on the balance sheet. In interpretation of Position of the Ministry of Finance of the Russian Federation [8] financial asset represents an object:
- on which a duly executed documents, confirming the legal right of entity on financial investment and obtaining from the debtor's funds or other assets, which enshrines this right;

- with the acquisition of which the legal entity exposes itself to financial risks associated with the financial investment, in particular, the risk of the asset price changing, the risk of debtor insolvency;

- having prospects of economic benefit -reception by the legal entity in the future per cents, dividends or growth in value. In particular, in the form of difference between the sale price (repayment by the debtor) of financial investment and its purchase price as a result of its exchange, usage at repayment of obligations of the organization, its increase of current price in the market.

In point 3 of Provision of the Ministry of Finance of the Russian Federation [8] is established that to financial investments of legal entity belong: the state and municipal securities, securities of other organizations, including debt securities in which date and cost of repayment are defined (bonds, promissory notes); deposits in authorized (folding) capitals of other organizations (including subsidiaries and dependent economic societies); the loans provided to other organizations, Deposits in credit institutions, the receivable acquired on the basis of assignment of requirement. That list of financial assets is not exhaustive. Thus, in point 4 of Provision of the Ministry of Finance of the Russian Federation [8] is accurately regulated that the assets having materialphysical form, namely - fixed assets, material-physical stocks, and also intangible assets are not financial investments.

Similarly, if for legal entities digital objects can at least be compared with regulated financial investments, the legal regulation of relations on investments in digital objects by an individual which not an individual entrepreneur, at the beginning of 2018 is not yet fully available. We should repeatedly marks that legal entities are not required for operations with ciphers.

The financial quality of an asset (investment) always implies the monetary liquidity of the object of ownership, namely, its ability of quickly turning into currency - money in cash (banknotes) and/or in non - cash form (recording the amounts of money in accounts with credit institutions). A financial asset is a material benefit for the future and for its reception by a subject by a specific transaction, that is, money was previously invested in some object in a certain amount. Alienating your financial asset after a certain period of time, the entity gains higher amount than invested previously. With this positive development of events, the wealth of the subject increases, and its measurement is carried out anew, but again in terms on money.

Considering the above-mentioned regulatory regulation of a financial asset in the decision of the Ministry of Finance of the Russian Federation [8], we come to the conclusion that digital objects cannot be classified as financial assets. First of all, because there is no basic legal feature - the subject who acquires digital objects for money does not have any documents that would confirm the fixation of the right to 
receive funds from a particular debtor, and the law itself does not arise, since a particular debtor does not exist, the legal relationship is not properly built.

\section{B. Varieties of digital assets: cash and equity surrogates}

As shown earlier, the basic concepts used in the draft Federal Law "On Digital Financial assets" [6] include, in particular, "digital financial asset". According to the lawyers of the Ministry of Finance of Russia is a property in electronic form. Such property is created by using encryption tools on your computer in any subject according to his will and his interests. The ownership rights of subjects to these ciphers are certified by entering records (also digital) into a special database.

The draft Federal law provides 2 versions of these codes: "cryptocurrency" and "token". Therefore, according to the draft law, the legal nature of digital objects is long (at least 50) sets of Arabic numerals with cipher functionality. Next, let's us consider what a positive social good to meet the legitimate and urgent moral and valid human needs presented in the draft of the Federal Law " On digital objects"? Who generates demand for ciphers, who provides their supply?

Terminologically, "cryptocurrency" in the draft law is absurd. "Crypto" is a encryption. Therefore, the term "cipher Suite" will be identical. The Federal Law "On Currency Regulation and Currency Control" [9] in article 1 establishes that currency is, first of all, the currency of the Russian Federation:

a) Currency as a banknotes and coins of Bank of Russia which were in the circulation as a legal means of cash payment in the territory of the Russian Federation, and also the seized or withdrawn from the address, but the specified banknotes which are subject to exchange;

b) Funds in Bank accounts and Bank deposits;

secondly, it is also a foreign currency:

a) Currency in the form of banknotes, treasury notes, coins in circulation and which are a legal means of cash payment in the territory of the relevant foreign state (group of foreign States), as well as seized or withdrawn from circulation, but the specified banknotes which are subject to exchange;

b) funds in Bank accounts and Bank deposits in monetary units of foreign States and international monetary or settlement units.

Based on the norms contained in the Federal Law "On Currency Regulation and Currency Control" [9], digital objects-ciphers have no state bindings at all, nor were not on any Bank accounts, calling them currency - illiterate and illegal. The definition of crypto currency in the draft Federal Law "On Digital Financial Assets" is surprising [5]. It said that crypto currency is a kind of cipher created and accounted for in a certain register of operations with ciphers, and not by some state, as befits a real currency, but by the participants of this register in accordance with the rules of the register of operations with ciphers. Even more vague is the interpretation of the registry members - are any persons who carry out operations with ciphers in accordance with the rules of the registry operations with ciphers. As we can see, in response to our questions raised above, there is an answer - it is only the participants by themselves (any person) who have ciphers, offer them for money, and other participants of cipher operations (also any person) exclusively in their own interests and voluntarily have demand and pay money for them. The mentioned rules of maintaining the register of operations with ciphers - by whom are made, by whom are approved, where are published - it is not unclear, all this is left without the slightest attention in the draft Federal Law.

It should be separately pointed out that, according to the lawyers who developed the text of the draft law, all cipher operations occur as if in a vacuum, to any space, time and a specific circle of persons projected norms do not apply. At the same time, in reality all encryption operations occur with the use of computers and special computer programs, with the obligatory connection to the well-known information and communication network "Internet". But we are faced in the draft Federal Law "on digital financial assets" with innovation in lawmaking - regulation, figuratively speaking, hovers over public relations: "Federal law regulates relations arising from the creation, production, storage and circulation of ciphers...", where, between whom and whom - it does not matter for the Ministry of Finance of Russia. Especially negatively and sharply looks in the text of the bill full absence even a hint on cooperation of the state and subjects of those relations which regulation is aimed by the Ministry of Finance of the Russian Federation. In our opinion, such cooperation is necessary and inevitable [10].

As we noted above, the 1st kind of digital objects from the draft Federal Law, illiterate and against the right called "cryptocurrency", can be understood as a cryptographic instrument (cash surrogate). Also in the draft Federal Law we find the 2nd version of digital objects - "token". In our opinion, this term is used quite unsuccessfully, and the digital object called "token" does not reflect the essence and functionality of this cipher at all. All modern users of mobile banking, performing Bank transfers, using computers with a mandatory connection to the information and communication network "Internet", have long been familiar with and have the skills of using tokens for personal authorization themselves, as a subject, remotely, outside the Bank managing the Bank account and carrying out cash payments. A token is a physically existing compact device, similar to a keychain, inside of which electronic micro-components and parts are interconnected in a certain way. This compact device is attached to the owner of the computer (necessarily connected to the information and communication network "Internet") as a key, and then gets access to your Bank account and disposes sums of money.

In our opinion, the well - established understanding of the term token - electronic key-should not be distorted and given a different meaning to it in Federal law. In the draft Federal law, a token is a type of cipher, which is issued by a legal entity or an individual entrepreneur in order to attract financing and is taken into account in the register of digital records. What is the register of digital records, by whom is it kept, where is it stored ... we cannot find anywhere in the draft Federal Law. In the fog of non-Russian words that for 
some unknown reason drawn to the project of the Federal Law, after all, the 2nd kind of digital objects "token" we can understand as a chipremoving tool (equity substitute).

There is a wide range of tried and tested means of attracting investments at the regional level. For example, in 2017 Volgograd region placed the entire issue of its coupon bonds RU35007VLO0 with par value of 1000 rubles in the amount of 10 million units in the amount of 10 billion rubles on the Moscow exchange WAP [11]. In our opinion, the mechanism of acquisition of shares of an economic entity by its major partner is quite efficient. So, in 2015 in our region set in service the plant of the portfolio company RUSNANO CJSC "Nikomag" which is producing nanostructured magnesium hydroxide (effective fire retardant), high-pure magnesium oxide (transformer steels and rubber products) and magnesium chloride (oil and gas production, production of building materials, fight against icing of designs and mechanisms). The total budget of the project is 3.8 billion rubles, of which RUSNANO investments in shares -1.3 billion rubles.

Unfortunately, projects in the nanoindustry that exist in our region [12], and which we consider to be breakthrough for the positive dynamics of the economy of the region, are very rarely given attention, as the Ministry of Finance of Russia and the Federal legislator. Although in the current sanctions period, this direction of production of goods is promising [13].

\section{CONCLUSION}

The analysis of the provisions of the draft Federal Law "On Digital Financial Assets" in general leads to the realization that with all the unprofessional legislative techniques reflected in the text of the bill, it is still seen quite obvious fiscal framework of the regulation. So, point 1 of article 4 of the draft Federal Law "On Digital Financial Assets" [1] established that owners of ciphers have the right to make transactions on exchange of ciphers of one type on ciphers of other type and/or exchange of ciphers for rubles, foreign currency and/or other property only through "the operator of digital financial assets exchange".

Unfortunately, this rule will be very difficult to implement, especially given that such transactions entities around the world have been conducting for the ninth year, without asking permission from any states, and without referring to any exchange operators. The most important thing is that this world cipher game was originally conceived and implemented in the information and communication network "Internet" on a decentralized basis, in secret from the state regulatory authorities and centralized operators. The mystery of this world-wide cipher game is provided by the same numbers that can not be hacked to get factual information about the subjects of transactions with ciphers, transactions in the monetary dimension.

According to the developers of the draft Law, such "operator of the exchange of digital financial assets" may be a legal entity that meets the requirements of the Federal Law froim November 21, 2011 № 325-FL (ed.from 18.07.2017) "On Organized Trading" [14] - is an exchange or a trading system. The Ministry of Finance of the Russian Federation is the centralized operator base in terms of tracking the revenues received by entities from operations with ciphers. We have no idea how specialists of the Ministry of Finance of Russia sees the tax base in the transaction, for example, the exchange of one subject code of 108 digits to another subject to the code of 93 digits, what amount in rubles in this transaction should be charged, and what kind of tax? Obviously, if the subject previously bought a certain code for money, and after a while, selling the same code for money, too, resulting in "earned" money income, then it will be clear a fiscal interest of the Ministry of Finance of Russia, aimed at this positive financial difference. And it is likely that in next year in the tax Declaration for 2018, a certain individual, we will see a miracle of self - employment of the XXI century is the income received by a citizen from operations with ciphers in the information and communication network "Internet".

It is possible to hypothesize that some legal entity in the Volgograd region is really officially reflected in the tax accounts for 2018 all its cipher operations. Such income of the organizations belongs to non-operating income which is taxed on profit of the organizations at the rate of $20 \%$. From this tax exemption, most of the proceeds $-75 \%$ - are credited to the budgets of the regions. According to our estimates, the probability of such legal entity taxes declaration of the authorities of the Volgograd region, reflecting its operations with ciphers, is zero.

It is also possible to assume that there would be in the Volgograd region individuals who, at the end of 2018, would reflect in their tax returns their operations with codes. Then we will be talk about the emergence of a tax base, taxable on the income of individuals from this tax withdrawal, even more of the income $-85 \%$ - is credited to the budgets of the regions. According to our indirect estimates, the region is systematically engaged in Internet operations with ciphers no more than 50 people, the tax base can be recorded on the results of their activities for the year within 10 million rubles. Of course, assuming that all of these individuals will actually be found, and the income receiving by them is proven.

In this regard, we come to the conclusion that the Federal law will have very little impact on the development of tax potential and investment at the level of the Volgograd region, having been adopted without changes in the draft.

We believe that the operations with ciphers fixed in the Federal Law "On Digital Financial Assets" [6], carried out by any persons in the world Internet space, the essence is a global computer playing for money. Moreover, involvement in the financial pyramid a mass of anonymous participants, the identification and protection of the rights of which under the terms of this game is priori impossiable. In our opinion, the draft Federal Law should be called "On Operations with Ciphers in the information and communication network "Internet"". Legislative interpretations of the two types of these ciphers and a number of other provisions should be completely revised. Assessing the draft law prepared by the Ministry of Finance of Russia for the digital economy as an imperative of financial policy, in general, should be 
recognized as an unviable, idle impulse. The presented model of state regulation will not have a positive impact on the increase in investment activity, the development of the tax potential of the regions of the Russian Federation.

\section{References}

[1] Inshakov O. V. Economic Institutes and Institutions: On the Issue of Typology and Classification. // Sociological Research. 2003. №9. p. 4251.

[2] Danilina E. budget Revenues of the Volgograd region increased by six billion rubles. // http://mr34.ru/2018/01/22/_bidget_volgograd_/.

[3] "Comments about the state and business". N R U "Higher school of Economics". // https://dcenter.hse.ru/data/ 2017/08/15/1174143980/KGB_138.pdf.

[4] Inshakov O.V. Inconsistency of theory, policy and practice of clustering in modern Russia // International Journal of Trade and Global Markets. 2017. Vol. 10 No. 2/3. Pp. 198-206. DOI: 10.1504/IJTGM.2017.10006606.

[5] Latukhina K. Figure and Facts. // https://rg.ru/ 2017/06/04/regszfo/vladimir-putin-vnedrit-cifrovye-tehnologii-vo-vse-sferyzhizni.html.

[6] Russian Federation. Federal Law "On digital of financial assets" (Draft). https://www.minfin.ru/common/upload/library/

2018/01/ main/Zakonoproekt_o_TSFA_250118_na_sayt.docx.
[7] Approval of the Accounting regulation "Accounting of Intangible Assets" (PBU 14/2007) (approved by the order of the Ministry of Finance of the Russian Federation from 27.12.2007 № 153n, with changes from 25.10.2010 № 132n, от 24.12.2010 № 186n, from 16.05.2016 №64n).//https://www.minfin.ru/ru/perfomance/ accounting/accounting/legislation/positions/.

[8] Approval of the Accounting regulation "Accounting of financial investments" PBU 19/02 (approved by order of the Ministry of Finance from 10.12.2002 № 126n, with changes made by orders of the Ministry of Finance of the Russian Federation from 18.09.2006 № 116n, from 27.11.2006 № 156n, from 25.10.2010 № 132 n, from 08.11.2010 № 144 n, from 27.04.2012 № 55n, from 06.04.2015 № 57n). // https://www.minfin.ru/ru/perfomance/accounting/ accounting/legislation/positions/.

[9] Federal law from 10.12.2003 № 173-Ф3 (edit from 29.12.2017) «On currency regulation and currency control». // «Russian newspaper», № 253, 17.12.2003.

[10] Inshakov O.V. Collaboration as a form of knowledge-based economy organization // Economy of region. 2013. №3 (35). Pp. 45-52.

[11] The order of the Committee of Finance of the Volgograd region from 16.01.2018 № 8 «On approval of the report on the results of the issue of government securities of the Volgograd region for 2017» // http://volgafin.volgograd.ru/upload/iblock/f03/Prikaz-komiteta-obutverzhdenii-otcheta-ob-itogakh-emissii-za-2017-god.pdf.

[12] Inshakova E.I., Inshakov O.V. World market for nanomaterials: structure and trends. // MATEC Web of Conferences. Volume 129, 2017. International Conference on Modern Trends in Manufacturing Technologies and Equipment (ICMTMTE 2017). DOI: https://doi.org/10.1051/matecconf/201712902013. 